Lorna Gibb is a Senior Lecturer of Creative Writing at the University of Hertfordshire. She is the author of Domains in Phonology (Sheffield University Press 1993) Lady Hester (Faber 2005), West's World (Pan Macmillan (2013), A Ghost's Story (Granta 2015), Childless Voices (Granta 2019). Correspondence to: Dr Lorna Gibb, Faculty of Humanities, University of Hertfordshire, de Havilland Campus, Mosquito Way, Hatfield AL10 9EU. Email 1.gibb@herts.ac.uk

\begin{abstract}
This article considers the career and life of Jessie White Mario. Her journalism and writing offers a unique perspective on the tumultuous period of Italian history, during the Risorgimento, yet is often overlooked. Her later work highlighting the terrible plight of workers in Sicilian sulphur mines was fundamental in raising awareness of their situation. Yet, it too is largely unknown in the country of her birth. Motivated by the love of a country that was not her own, defiant of the strictures and expectations placed upon her, because of her gender, White Mario is a figure that should be celebrated and remembered, not consigned to future neglect.
\end{abstract}

\title{
Hurricane Jessie
}

\section{By Lorna Gibb}

Jessie White (1832-1906) journalist, biographer, nurse stormed across the history of nineteenth century Italy like a hurricane. 'L’Urgano' was a nickname that long 
outlived her, as did admiration, respect and love for the fiery British redhead who fought so fiercely for her adopted land. A heroine of the Risorgimento, the struggle for Italian Unification, her passion and her politics endeared her to the Italian people who took her to their hearts. Britain was less enthusiastic; Jessie's outspoken tirades and peremptory manner were not ideal reflections of English Victorian womanhood. Her political involvement with Italian partisans was seen as a diplomatic embarrassment, so much so that while Mazzini hailed her as the Joan of Arc of Italy, the British authorities refused to intervene when she was imprisoned and conspired to have her declared insane.

Yet White was more than a political campaigner for Unity; she was also the first female journalist writing in English and the first observer of the hidden nature of Italian society. Her copy was detailed and unsparing, and when Britain and America learned of the unification of Italy, it was largely through her journalism. Later, after the country was unified, that same writer made the rest of Europe aware of people living in cavernous underground slums in Naples and of children as young as eight toiling in sulphur mines in Sicily.

Jessie White's early life was restricted and conventional. She was brought up in 1830s and early 1840s Gosport by her father and a step-mother, in a home dominated by the narrow Puritanism that so obsessed her father. However, while her brother, Fred, followed in the paternal footsteps, embracing the strict tenets and biblical teaching of their daily life, Jessie rebelled. She boasted that she argued constantly with her 
brother and her father and wrote long essays in her notebooks questioning Christian morality.

Yet surprisingly, and in spite of this conflict, Jessie's memories of her childhood were happy ones, showing her to be a reluctant student who enjoyed playing games with Fred and her half-brother, Harry.

Her interest in education changed dramatically when she met John Daniel Morell, an unconventional and outspoken preacher who captivated Jessie from their first meeting in 1842, when she was just ten. His European education and religious sensibilities, which combined the newest philosophical thought with bible teachings, attracted and enchanted her. She found new meaning in his analysis of texts and a practical application of it in her works for the local poor whom she proceeded to visit and give food to, often to the consternation of her step mother. It was through Morell that Jessie first became interested in European current affairs.

In 1843, Italy was recovering from a series of insurrections that had erupted the previous decade. Many of these were the result of a revolutionary group, the Carbonari, who, inspired by the French revolution, aimed to unify the disparate states of Italy as one republican nation. Joseph Mazzini, a figure who would come to dominate Jessie's life, was a prominent member of the organization, from 1830. And Guiseppe Garibaldi, a key figure for Jessie, was yet another Carbonari, one who had already been sentenced to death for organising an uprising in Piedmont in 1834. 
Both men were living outside Italy; Garibaldi was far away in South America, while Mazzini was still controlling revolutionary activity from his base in Marseille. The 1840s saw massive changes in legislation, enforced by the Papal States, and designed to quell the unrest. They had the opposite effect, and groups against the occupying Austrians in the North, the Bourbon rulers in the South and the Papal States grew in number. The idea of an Italian Republic, free from what was regarded by many liberal thinkers as an evil Austrian regime, was embraced by many British liberals; Jessie's teacher was no exception. By 1844, Jessie already had opinions about Europe and made a few brief references in notebooks to 'Austria's tyranny' in some parts of Northern Italy. ${ }^{1}$

Alongside these political observations, short stories highlighted her growing interest in community aid and social reform, issues that would be driving forces throughout her adult life. When her family relocated to Portsmouth, Jessie studied for a time at a school in Reading, before being enrolled at another school in Birmingham when she was seventeen. This latter was a fortuitous choice, run by the wife of Morrell's close friend, George Dawson. Dawson was a liberal church reformer, responsible for England's first public library, as outspoken in denouncing slavery as he was in advocating a better education for women. A follower of John Stuart Mill, he believed that prosperity would only come through improved and equal education, when every member of a community was literate and aware of his responsibility to others around him or her. Jessie's conversations with him and education by his wife were probably pivotal in her later stance against the papacy. ${ }^{2}$ Dawson, like Morrell, regarded as the papacy as corrupt and believed that Austrian and Bourbon occupation suppressed Italian freedom. 
Jessie's opinions were cemented irrevocably in 1854 when, accompanying her friend Emma Roberts to Nice, she met Garibaldi for the first time. Garibaldi, since the death of his wife, had two reputations, one as a great fighter and leader, the other as a lover of women. Emma's brief meeting with him on an earlier European trip had led her to believe they were engaged. Taking her friend, Jessie, as a companion, she went to join him.

Nice was Garibaldi's place of birth. Crippled by rheumatism, he was recovering from the revolutions of 1848 and 1849 which had seen them take Lombardy from the Austrians, and declare a Republic in Rome, only to lose Lombardy again and to be defeated by the French who occupied Rome to restore Pope Pius IX in response to his request for aid. The trip to Nice meant that he could see his children for the first time in five years. He settled in a cottage, taking with him his seven year old boy, Ricciotti. Emma and Jessie had a house nearby and the four spent most of their time together, eventually moving on as a group to Sardinia. Garibaldi regaled them with the events in Italy, and when they left him to make a tour of Italy they did so armed with introductions to many of the General's supporters, including Elizabeth Barrett Browning, with whom Jessie struck up a friendship.

When they rejoined Garibaldi, they found him excited by Sardinian support for Britain and France in the Crimea. Garibaldi firmly believed that this show of solidarity would bring their cause the goodwill of France and Britain. Their enthusiasm was not shared by the visionary Mazzini. He felt that if Austria joined in 
the war against Russia it would provide the ideal opportunity for Sardinia to attack Austria's over stretched resources thus freeing Lombardy and Venezia.

In time, Jessie would become involved in the dispute that ran between the two men, but during this first encounter, her primary preoccupation was Garibaldi's more domestic concerns. Ricciotti was having trouble walking, his legs were weak and showing signs of further deterioration. When Jessie returned to London, she took Garibaldi's son with her so that he could be treated by expert surgeons there. He made a complete recovery and remained in England to complete his education.

Buoyed by Garibaldi's faith in her, Jessie decided that she could best serve Italy by tending to its wounded. She resolved to 'secure the best medical education possible' and applied to 'all the London hospitals - fourteen in number' that she might be admitted to study to become a doctor. ${ }^{3}$ Throughout the early summer she received refusal after refusal but remained confident that the University of London, famed for its liberalism, would admit her. By late July, it was clear that they too, would not.

In her new role, as defender of Italy, Jessie was gradually being introduced to a social circle of like minded people. In particular she became attached to a group in London known as the Friends of Italy. This was a rather scattered array of intellectuals and political activists who helped raise and divert aid to Mazzini who was exiled close by. The Ashurst Family were the founders and lived in Muswell Hill. William Ashurst was a barrister who had first got involved when he was outraged to learn that Mazzini's mail had been opened and read by the British government. Mr and Mrs Ashurst sent their son and eldest daughter, William and Eliza, to Mazzini to express 
their regret at his treatment and to invite him to dinner. Emily, the youngest Ashurst daughter, like Jessie, would become one of Mazzini’s most devoted admirers. Yet this shared admiration would not suffice to build a friendship between the two women. Over time their initial wariness would deteriorate into enmity and outright bitching between the two women, reminiscent of the feud between Garibaldi and Mazzini, despite their common beliefs.

It was through the Ashursts that Jessie had her first meeting with Mazzini. In 1856, Mazzini was living in a tiny room in Cedar Road, surrounded by the birds he loved to tame and keep as pets. When she arrived she found him almost engulfed by the scattered books and papers which covered every surface. Jessie wrote of their encounter:

He rose at once: his hand grasp and luminous eyes fascinated and encouraged you, yet filled you with momentary awe. But the simple greeting, the gladness shown in welcoming 'one more volunteer to the noble band of English workers and lovers of Italy' put all fears to flight, and soon he was talking, and I was listening as a student to a master, anxious to convince... ${ }^{4}$

Jessie's enthusiasm for Mazzini was not completely reciprocated. When Emily wrote to Mazzini of her misgivings about the newest member of their circle, he replied:

I do not wonder much at what you say about Jessie, and your feelings. There is, physically too, something dry in her, something too manly., ${ }^{5}$ 
Unaware of these misgivings in the man who would become her hero, Jessie left the encounter deeply affected; Mazzini would become the greatest influence in her life over the coming decade, crucially changing her relationship with Garibaldi.

Her personal relationships with the key figures of the revolution, Garibaldi and Mazzini, grew to be no less fraught than their relationship with each other. Through her newspaper articles, her biographies, and in her copious journals and diaries, we can almost feel the charisma and force of these two figures; in their recollections and descriptions of her we see a complex heroine, passionate and fiery, infuriating but adored: a tireless fighter for those whom she believed to be downtrodden or oppressed. And in spite of her arrogance and dogmatism, she was a woman who was a loyal, almost worshipful, disciple of the men she admired. Yet those who admired her, and even benefitted from her political passion and astuteness, criticised what they perceived as her masculine manner. In time, Mazzini would fully acknowledge the value of her role in his fight, but continued to despair that:

Good and devoted as she is, Jessie infuriates me. She talks like a soldier; she insults everyone; she uses a dictatorial manner which is more imperious than Garibaldi's own.' 6

Finally, after accepting that first her medical ambitions and then, with Mazzini’s criticism, her leadership hopes, had been thwarted, Jessie wholeheartedly embraced the alternative possibility that Mazzini offered. She began a lecture tour of Britain, speaking about 'The Italian Question' in an attempt to gather British support, and finances. 
Meanwhile the relationship between Garibaldi and Mazzini was strained again. Mazzini was planning an expedition on Naples with Pisacane, one of his staunchest supporters, and a man who had hidden him, at risk of his own life, in the past. Naples and Sicily, known as the Kingdom of the two Sicilies, was under control of a Bourbon King, who was notorious for the brutality of his regime. A previous plot, where a steam ship laden with weapons to use against the revolutionaries was blown up, had failed to rouse the public, so many felt that it was not the time to agitate further in the region.

However, Pisacane was convinced that with Garibaldi's leadership, and the popular support it guaranteed, any future events would be more successful in stirring the population to action. But Garibaldi refused. Jessie was outraged and wrote to Garibaldi urging him to reconsider. His answer infuriated her further, couched as it was in the romantic language he frequently used to appease other 'sisters in the faith': Well I love you, which matters very little to you; I love you for myself and for my boy, and for Italy. ${ }^{7}$

Jessie was at pains to point out in her history that several of his female followers took these outpourings the wrong way, 'mistaking his patriotic outpourings for personal affection for themselves, received [them] as love letters—one, indeed, insisting that they entitled her to marriage'. ${ }^{8}$

By April 1857, Mazzini and Pisacane decided to push ahead with their plans regardless of Garibaldi's refusal to participate and Jessie went to Genoa to help them. 
Although ostensibly there to work as a journalist, Jessie's request to cover events had been refused, and she acted as a messenger for Mazzini and Pisacane. The final plan was to capture the postal steamer, the Cagliari, disarm the garrison on the Island of Ponza, then storm the prison of the Bourbons, releasing the political prisoners and returning with them. On their return they were overpowered by Bourbon troops, supported by the very masses they had hoped to win for the cause. Pisacane fell with the one hundred and eleven men who died that day and was so badly mutilated that his face was said to unrecognisable. ${ }^{9}$ Back in Genoa, Mazzini managed to escape, but Jessie was arrested, as was Albert Mario, another compatriot in the attempt. Jessie remained in prison for five months. The British, reluctant to have a trial where her outspoken outbursts might be an embarrassment for them, conspired to have her proved insane. However when the warders were called upon to testify to her insanity, one even declared to the judge that she was 'more wide awake than you are!' 10

Apart from beginning a schism with the British establishment, Jessie's imprisonment had another significant consequence. She and Alberto fell in love and, as soon as they were released, they were married. In a bid to raise more money and publicity for the cause, they honeymooned in the States where Jessie gave a series of lectures on the 'Italian Question'. Against all the predictions and expectations, her marriage was a happy relationship, with a man said to be as difficult and dogmatic as she was. Their love for each other was in marked contrast to the troubled associations that were a recurrent symptom of Jessie's turbulent personality. Elizabeth Barret Browning, faced with Jessie's growing involvement with the more extreme revolutionary movements, felt forced to make a public statement at the Athenaeum, disassociating herself from her erstwhile friend: 
We entirely dissent both from her views of Orsini and her opinions upon Piedmont, considering that every attack upon the Piedmontese government is levelled also against the Italian cause. ${ }^{11}$

However, admirers of her enthusiasm and outspoken bids for reform, were equally numerous. Both George Sand and Florence Nightingale actively supported her and Carducci, the Italian laureate of 1906, summed up her contribution to his country in his 'Confessioni e Battaglie' by describing her as 'a great woman to whom we Italians owe so much'. ${ }^{12}$

In the final campaigns, Jessie found her place with Garibaldi again, both as a War correspondent, reporting on some of the goriest battlefields of the conflict, and as a nurse. Her bravery in physically rescuing men from the frontline was regularly reported in the Daily News. During one battle she reportedly made fourteen sorties under fire, to bring back the wounded, and to take water and fruit to those who remained fighting. ${ }^{13}$ In the teeming, filthy field hospitals that lay in the wake of the battles, she acted as nurse and manager, aiding in amputations, taking charge of the limited supplies. Admired and praised, even by those who did not approve of her, the Daily News reporter wrote, grudgingly, on $25^{\text {th }}$ September 1860 :

I utterly reject her lack of principles, as fraught with danger to the peace and liberty of Italy but I admire her merit in the management of hospitals, and in the sacrifice of time and repose which she made for a great benevolent object. $^{14}$ 
Throughout all of her adventures, Jessie continued to write, for she was not only a political activist, but the first female foreign correspondent, and a skilled biographer. Her life stories of Mazzini, Garibaldi and Cattaneo, amongst others, and her unfinished manuscript of the life of James Stansfield, gave British readers their first insight into the previously enigmatic characters who had wrought such turmoil in Europe. For newspapers in Britain, and later in the States she wrote opinionated, detailed accounts of Italian events as the Risorgimento unfolded, never hesitating to criticise those countries for what she saw as their failure to support Italy. They did not always print what she wrote, and many of her supporters despaired of the way they were edited, but nevertheless many people saw the upheaval in Italy through the eyes of Jessie White.

After the Unification, the continuing divisiveness of the new nation, and its inequity, became the topics which replaced her stories of frontline battles. She renewed her interest in medicine and began methodical research into the disease Pellagra which was endemic in the slums of Southern Italy. Caused by a deficiency of niacin, this fatal disease begins with a rough skin rash from whence the disease gets its name; 'pellagra' is Italian for rough skin. Diarrhoea and dementia quickly follow the initial signs. ${ }^{15}$ Jessie's work and reports on both the conditions that led to the disease and its effects, also served to highlight the inequalities of what she would describe as her 'unsatisfactory revolution'. ${ }^{16}$ Several decades before 1914, when scientists would officially declare that pellagra was caused by a deficiency of some nutrient in the diet, Jessie White Mario was making huge improvements in Southern Italian slums by changing the diet of the poor in the limited ways possible. Red wine was cheap and 
abundant and a ready source of niacin; Jessie reported that a glass or two a day showed dramatic results. ${ }^{17}$ Likewise, she felt the condition was exacerbated by blighted grain, something that would be confirmed by later research. ${ }^{18}$ Well into her sixties, and despite her rapidly failing health, she also campaigned against the child labour of the Sicilian sulphur mines. Her published report, Le Miniere di Zolfo in Sicilia in 1894, was the catalyst for the subsequent government investigation that brought reform. ${ }^{19}$ When Jessie died in 1906, it was with the knowledge that many improvements had been made, thanks to her tireless exposure of the appalling conditions and inequalities that lay behind the country that she loved.

Jessie's story is that of a woman with a belief, a belief in a theoretical system whose practical implementation fell, and for some still falls, far short of the ideal it was created to promote. Today, the differences of the uneasy alliance are reflected in the popularity and number of political parties arguing for further autonomy within the regions, or even, in the case of some minority parties, independence. The Northern League aims to achieve an independent coalition of Northern regions, able to enjoy their own industrialised prosperity, freed from what the party sees as financial obligation and subsidy to the poorer South. The Alto Adige/Sud Tirol still shows some of the Italian-Austrian tension of the war that raged in the late nineteenth century. Dialectic differences are as strong now as they were a hundred years ago, and many regions employ these almost exclusively in social contexts, in defiance of the idea of a common Italian. ${ }^{1}$

\footnotetext{
${ }^{1}$ Scotland has now devolved from England yet their union is more than four hundred years old; Italy has been a united republic for less than half of that. Differences are inevitable, but also easier to understand by considering the background that created this uneasy alliance, one that was reflected in the troubled relationships of the men and women who forged it.
} 
Jessie was a journalist who set out not only to report on what she observed but to bring about change by doing so. Rarely, if ever, has anyone been so successful at both. In her writing, we see the dissension and dissonance of different personalities, united by a common cause, and we see these same attributes reflected in the new society. Her work offers literary accounts of a lost time as seen by a witness of the turmoil. Through her campaigning, we see the possibility, then the actuality, of change. Her role in the creation of today's Europe and her legacy, her papers, documents, books and articles recording the history of that time, as well as her small but crucial contribution to medical research, stand together as an undeniable testament to a woman of so many talents, motivated by the care of a nation.

\footnotetext{
${ }^{1}$ Archivo Jessie White Mario, Museo Centrale del Risorgimento, Rome, Busta 420 (a)

2 Jessie White Mario 'Religious Tolerance in Italy' in Nation 26 April 1866

${ }^{3}$ Jessie White Mario Birth of Modern Italy (London, Fisher Unwin, 1909) p253 and Barbara Leigh

Smith Bodichon, Women and Work, (London, John Murray, 1857) pp40-42

${ }^{4}$ Jessie White Mario, The Birth of Modern Italy, (London, Fisher Unwin, 1909 ) p260

${ }^{5}$ Guiseppe Mazzini Letters to an English Family 'To Emilie. October 25 ${ }^{\text {th }} 1856$ ' (London, John Lane, 1920) p61.

${ }^{6}$ Guiseppe Mazzini, Letters to an English Family 'To Caroline From Naples. November $1^{\text {st }}$ 1860'(London, John Lane, 1920) p260

${ }^{7}$ Jessie White Mario The Birth of Modern Italy (London, Fisher Unwin, 1909) p265

${ }^{8}$ Jessie White Mario The Birth of Modern Italy (London, Fisher Unwin, 1909) p264

${ }^{9}$ Jessie White Mario The Birth of Modern Italy (London, Fisher Unwin, 1909) p269

${ }^{10}$ Jessie White Mario The Birth of Modern Italy (London, Fisher Unwin, 1909) p273

${ }^{11}$ The Athenaeum No1644 (April 30 1859) p584

${ }^{12}$ Carducci, Giosue Confessione e Battaglie Ditta (Bologna, Nicola Zanichelli, 1890) p192

${ }^{13}$ Miriam Urban, British Opinion and Policy on the Unification of Italy, (UK, Mennonite Press, 1938) p555-557

${ }^{14}$ Daily News $25^{\text {th }}$ Sept 1860

${ }^{15}$ See Kenneth Carpenter (ed) Pellagra (London, Hutchinson Ross, 1892), and Miseria e malattie nel XIX sieclo: Miseria e malattie nel XIX secolo: I ceti popolari nellItalia centrale fra tifo petecchiale e pellagra : [antologia] (La società italiana moderna e contemporanea) (Roma, Angeli, 1973).

${ }_{16}^{16}$ Busta 419, Archivo Jessie White Mario in the Museo Centrale del Risorgimento, Rome

${ }^{17}$ Busta 437 Archivo Jessie White Mario in the Museo Centrale del Risorgimento, Rome

${ }^{18}$ Busta 437 Archivo Jessie White Mario in the Museo Centrale del Risorgimento, Rome

${ }_{19}$ Jessie Mario White Le Miniere di Zolfo in Sicilia (Sicilia, Tipografia della Camera dei Deputati, 1894) 71pp
} 